\title{
Crude Protein, Crude Fiber, Tannin, and Oxalate Concentrations of 33 Astragalus Species
}

\author{
A.M. DAVIS
}

\section{Abstract}

Plant introduction collections grown at the Western Regional Plant Introduction Station for preliminary evaluation and seed increase were evaluated for crude protein, crude fiber, tannin, oxalates, and readily detectable alkaloids. Sixty-eight $A$ stragalus accessions representing 33 species and 1 unidentified accession had a range of 8.2 to $24.2 \%$ crude protein, 11.3 to $28.6 \%$ crude fiber, 4.2 to $10.0 \mathrm{mg} / \mathrm{g}$ tannin, and 0.15 to $1.10 \%$ oxalates. Species with more than $18 \%$ crude protein and less than $28 \%$ crude fiber (i.e., comparable to good quality alfalfa (Medicago sativa) hay) and acceptable levels of tannin and oxalate were $A$. canadensis, P.I. 19978 and $A$. siliquosus, P.I. 330696. None of the accessions tested gave a positive Dragendorff reagent color test for alkaloids. Some of the species reported are known to be selenium accumulators and/or contain toxic nitro-compounds that may be damaging to graxing animals. $A$. siliquosus is a species that contains nitro-compounds and will accumulate selenium.

The genus Astragalus is widely distributed throughout the temperate regions of the world, but is particularly abundant in the temperate regions of North America, Europe, and Asia. The most common use of Astragalus is forage for livestock and wildlife, but Uphof (1968) listed 32 species known to have been used by man for food, medicine, cosmetics, substitutes for tea or coffee, or sources of vegetable gums.

The USDA Plant Introduction System has introduced 99 species and many unidentified accessions of Astragalus in recent years. Some species have been shown to be selenium accumulators (Davis 1972). Only a few have had sufficient alkaloids to respond positively to a Dragendorff reagent color test as modified by Burns (1964) and reported by Davis (1973). Two introduced species, $A$. cicer and $A$. falcatus (cicer and sicklepod milkvetch), are being used in range revegetation and reclamation (Barneby 1964). Others are being evaluated for their forage potential.

Chamberlain and Matthews (1969) reported that the genus Astragalus has the most extensive speciation of any genus in Leguminosae, with 370 recognized species in Turkey. Komarov (1965) described 575 species of the known 849 species found in the USSR. Some of the species are known to exist in both countries. North American speciation has been cataloged by Barneby (1964), who recognized about 500 species and developed descriptions and distribution maps for 368 of these.

Seventeen of the 33 Astragalus species reported here were shown to accumulate selenium (Davis 1972); these species are sodesignated in Table 1. Investigations by Williams and Barneby (1977), Williams and James (1975), and Williams et al. (1976) have shown that nitro-compound toxicity is common in the Astragalus genus. They showed that five of the species presented here have proven toxic to animals. $A$. canadensis L. and $A$. falcatus Lam.

\footnotetext{
Author is research agronomist, Western Regional Plant Introduction Station, U.S Dep. Agr., Agr. Res. Serv.

This report is a contribution of the Western Regional Plant Introduction Station, U.S. Department of Agricultural, in cooperation with the College of Agriculture Research Center, Washington State University, Pullman 99164 . Scientific Paper No. 5195 of the latter.

Manuscript April 25, 1980.
}

appear to be among the more hazardous. Others with nitrocompounds were $A$. galegiformis L., A. kotschyanus Boiss., and $A$. siliquosus Boiss. Unpublished data from M.C. Williams show that A. filicaulis, A. glycphyllus, A. hamosus, A. odoratus, A. podocarpus, $A$. refractus, and $A$. trimestris also contain nitro-compounds in toxic quantities (personal communication).

\section{Materials and Methods}

The Astragalus species were grown at Central Ferry, Washington, and were of diverse geographical origins. The annual species were sampled and analyzed the season of establishment and the perennials were sampled and analyzed the following year. The soil was "Chard" coarse-loamy, mixed, mesic calcic haploxerolls, which developed on bars along the Snake River. This soil has generally good internal and external drainage. Water was applied throughout the growing season to maintain vigorous growth. Accessions were seeded in rows $1.5 \mathrm{~m}$ wide and $6 \mathrm{~m}$ long and after establishment were sidedressed with $67-87-0-11 \mathrm{~kg} / \mathrm{ha}$ (N-P-K-S). Nitrogen was added to assist in the breakdown of the barley straw from the previous crop year. Forage samples were taken from all plants to the row. Plots were cultivated and hand hoed for weed control.

The 68 accessions reported in this paper represent 33 species and 1 accession that has not been identified. These represent about one-third of the species held by the Western Regional Plant Introduction Station.

Whole stem samples were taken in duplicate from all aboveground parts of the plants at bloom stage; leaves, stems, petioles, scapes, and flowers were combined to make a composite sample. These samples were dried in a thermal draft oven at $80^{\circ} \mathrm{C}$, ground to 20 -mesh fineness and stored at $20^{\circ} \mathrm{C}$ and $35 \%$ relative humidity until analyzed. Crude protein was estimated by determining Kjeldahl nitrogen (AOAC 1970) and multiplying by 6.25; crude fiber was determined by the method outlined in AOAC (1970), tannin by the method of Burns (1963), and oxalic acid by the method of Dye (1956). All accessions were checked for alkaloids using the Dragendorff reagent color test as modified by Burns (1964).

\section{Results and Discussion}

The crude protein, crude fiber, tannin, and oxalic acid levels in various Astragalus species are presented in Table 1.

Crude protein variation was less in this collection than in the collection from USSR reported by Davis (1973). This report includes accessions from Europe and Asia, as well as from North America. The highest crude protein $(24.2 \%)$ was found in $A$. canadensis, P.I. 232539 from Wyoming, and the lowest $(8.2 \%)$ in A. missouriensis, P.I. 199780 from Canada. The average crude protein found in the annual species was $12.4 \%$; the average for the perennial species was $14.6 \%$. Only $A$. canadensis ( 2 accessions) and $A$. siliquosus equaled or exceeded the $18 \%$ found in good alfalfa hay (Miller 1958).

Crude fiber varied from $32.5 \%$ for $A$. boeticus, P.I. 23325, a large robust coarse perennial species, to $11.3 \%$ for $A$. edulus, P.I. 
244273, an intermediate-sized a nnual. Few accessions were as high in crude fiber as good alfalfa hay (28\%), as reported by Miller (1958). In fact, only three accessions exceeded $25 \%$ crude fiber (Table 1). When samples were collected at full bloom, crude fiber was low, as indicated by these data.

Annual species averaged less crude fiber than perennial species, $16.8 \%$ and $18.6 \%$, respectively. This overall crude fiber average was lower than previously reported by Davis (1973) and was due to a different species complex.

Tannin levels were generally low. Only two were higher than 10 $\mathrm{mg} / \mathrm{g}$. Donnelly and Anthony (1969) reported that more than 25 $\mathrm{mg} / \mathrm{g}$ tannin was required in Lespedeza cuneata (Dum.) G. Don before animal acceptance was impaired. The average levels found in this collection were $1 \mathrm{mg} / \mathrm{g}$ lower than in the previous report (Davis 1973), and no problems with acceptance due to tannin would be expected. The average for the annual species was 5.7 $\mathrm{mg} / \mathrm{g}$ and for perennials, $6.2 \mathrm{mg} / \mathrm{g}$.

Oxalates were particularly low. All were less than $1 \%$ with an a verage of 0.36 oxalic acid equivalent. Morton et al. (1959) reported that a mature sheep requires $45 \mathrm{~g}$ oxalic acid equivalent before toxicity would develop. On this basis, a sheep would have to ingest $12.5 \mathrm{~kg}$ of dry matter containing 0.36 oxalate before toxicity would develop. The average oxalate level for annual species was less than that for the perennials, $0.36 \%$ and $0.40 \%$, respectively.
None of the accessions in this collection produced a positive Dragendorff color test for alkaloids.

These results and the previous report (Davis 1973) indicate that forage quality in the Astragalus genus is highly variable among species and accessions within species. This is well illustrated by the 21 accessions of $A$. hamosus in this report. These varied from $14.2 \%$ to $10.7 \%$ in protein, from $21.0 \%$ to $11.9 \%$ in crude fiber, from $7.2 \mathrm{mg} / \mathrm{g}$ to $3.5 \mathrm{mg} / \mathrm{g}$ in tannin and from $1.10 \%$ in $0.15 \%$ in oxalates. Plants in this genus, with notable exceptions, are lower in crude protein and crude fiber than good alfalfa hay and none of the accessions analyzed had tannin levels or oxalic acid equivalents high enough to be dangerous or to curtail utilization by livestock.

Ranchers in western states need productive, quality leguminous forages that will grow in areas where alfalfa is not adapted. Some Astragalus species now being tested by federal and state agencies may meet this need, although feeding trials should be conducted before any accession is seeded for forage production to avoid introducing undesirable plants into the forage complex.

The utilization of some species or accessions may be limited by inherent characteristics such as poor seed production, selenium accumulation, inability to withstand repeated defoliation or drought, or the presence of alkaloids or nitro compounds. New research on Astragalus is locating accessions, free of such undesirable characteristics, that may become important sources of forage on farms, ranches, and ranges of western America.

Table 1. Protein, crude fiber, tannin, and oxalate content in 33 Astragalus species and 1 unidentified accession.

\begin{tabular}{|c|c|c|c|c|c|c|}
\hline Species acid & $\begin{array}{c}\text { Plant inventory } \\
\text { number }\end{array}$ & Origin & $\begin{array}{l}\text { Protein } \\
(\%)\end{array}$ & $\begin{array}{c}\text { Crude fiber } \\
(\%)\end{array}$ & $\begin{array}{l}\text { Tannin' } \\
(\mathrm{mg} / \mathrm{g})\end{array}$ & $\begin{array}{c}\text { Oxalic } \\
(\%)\end{array}$ \\
\hline alpinus & 232536 & Wyoming & 16.6 & 13.6 & 5.9 & 0.91 \\
\hline americanus & 236743 & Canada & 14.6 & 16.1 & 5.9 & 0.89 \\
\hline bisulcatus ${ }^{2}$ & 241039 & Utah & 15.5 & 15.5 & 5.0 & 0.46 \\
\hline boeticus & 233225 & Israel & 14.5 & 32.6 & 5.5 & 0.19 \\
\hline campylorhynchus ${ }^{2,3}$ & 220280 & Afghanistan & 8.9 & 28.6 & 6.6 & 0.29 \\
\hline campylorhynchus ${ }^{2,3}$ & 220770 & Afghanistan & 10.2 & 25.8 & 6.9 & 0.24 \\
\hline campylorhynchus ${ }^{2,3}$ & 227008 & Iran & 9.9 & 21.4 & 5.9 & 0.22 \\
\hline canadensist & 199778 & Canada & 18.4 & 14.8 & 4.5 & 0.29 \\
\hline canadensist & 232539 & Wyoming & 24.2 & 15.8 & 5.9 & 0.29 \\
\hline charborasicus & 330693 & Iran & 13.8 & 23.3 & 4.5 & 0.24 \\
\hline charborasicus & 330694 & Iran & 16.7 & 24.1 & 5.9 & 0.28 \\
\hline cicer & 066515 & Turkey & 14.4 & 17.8 & 4.5 & 0.58 \\
\hline cicer & 206404 & Sweden & 14.9 & 17.7 & 5.5 & 0.51 \\
\hline cicer & 206405 & Turkey & 15.0 & 18.5 & 4.5 & 0.56 \\
\hline coluteocarpus & 223245 & Afghanistan & 11.2 & 19.8 & 7.2 & 0.23 \\
\hline commixtus $^{2,3}$ & 220161 & Afghanistan & 9.6 & 23.6 & 7.1 & 0.16 \\
\hline corrugatus $^{2,3}$ & 220156 & Afghanistan & 9.0 & 24.0 & 5.9 & 0.42 \\
\hline cymbacecarpos ${ }^{2,3}$ & 318944 & Spain & 11.6 & 12.7 & 5.0 & 0.60 \\
\hline cymbaecarpos ${ }^{2,3}$ & 318946 & Spain & 12.2 & 12.0 & 5.5 & 0.40 \\
\hline edulus ${ }^{2,3}$ & 244273 & Spain & 13.6 & 11.3 & 6.9 & 0.21 \\
\hline falcatus 2.4 & 066440 & USSR & 16.0 & 14.9 & 5.0 & 0.17 \\
\hline filicaulis ${ }^{2,3}$ & 220769 & Afghanistan & 11.2 & 21.7 & 7.2 & 0.27 \\
\hline filicaulis ${ }^{2,3}$ & 314141 & USSR & 11.9 & 17.7 & 6.9 & 0.25 \\
\hline galegiformis $^{2,4}$ & 206406 & Turkey & 15.5 & 15.1 & 7.2 & 0.34 \\
\hline globiceps ${ }^{2}$ & 172376 & Turkey & 14.4 & 20.9 & 8.6 & 0.21 \\
\hline glycyphyllus ${ }^{2,4}$ & 234686 & Denmark & 14.8 & 16.5 & 8.6 & 0.56 \\
\hline glycyphyllus ${ }^{2,4}$ & 235070 & Switzerland & 14.6 & 14.0 & 5.9 & 0.52 \\
\hline hamosus & 214096 & Spain & 13.7 & 13.8 & 6.9 & 0.16 \\
\hline hamosus ${ }^{3,4}$ & 214103 & Spain & 11.2 & 21.0 & 5.9 & 0.17 \\
\hline hamosus ${ }^{3,4}$ & 226627 & Iran & 11.0 & 19.6 & 5.9 & 0.23 \\
\hline hamosus ${ }^{3,4}$ & 227351 & Iran & 14.2 & 14.9 & 7.2 & 0.19 \\
\hline hamosus ${ }^{3,4}$ & 227440 & Iran & 13.7 & 14.4 & 5.7 & 0.28 \\
\hline hamosus ${ }^{3,4}$ & 244274 & Spain & 12.3 & 18.0 & 5.9 & 0.31 \\
\hline hamosus ${ }^{3,4}$ & 244275 & Spain & 13.9 & 17.7 & 5.9 & 0.17 \\
\hline hamosus & 244276 & Spain & 12.7 & 15.1 & 5.5 & 0.19 \\
\hline hamosus & 244308 & Spain & 13.3 & 13.3 & 6.4 & 0.38 \\
\hline hamosus ${ }^{3,4}$ & 287767 & Italy & 12.5 & 16.5 & 4.5 & 0.22 \\
\hline hamosus ${ }^{3,4}$ & 287768 & Italy & 13.5 & 12.0 & 5.5 & 0.84 \\
\hline hamosus ${ }^{3,4}$ & 287769 & Italy & 13.9 & 11.9 & 5.0 & 1.10 \\
\hline hamosus & 302856 & Italy & 14.0 & 12.9 & 4.5 & 0.21 \\
\hline hamosus ${ }^{3,4}$ & 302857 & Italy & 10.7 & 13.9 & 6.4 & 0.19 \\
\hline hamosus ${ }^{3,4}$ & 307949 & Algeria & 13.5 & 12.2 & 6.9 & 0.18 \\
\hline hamosus ${ }^{3,4}$ & 311360 & Spain & 13.6 & 13.4 & 3.5 & 0.15 \\
\hline
\end{tabular}




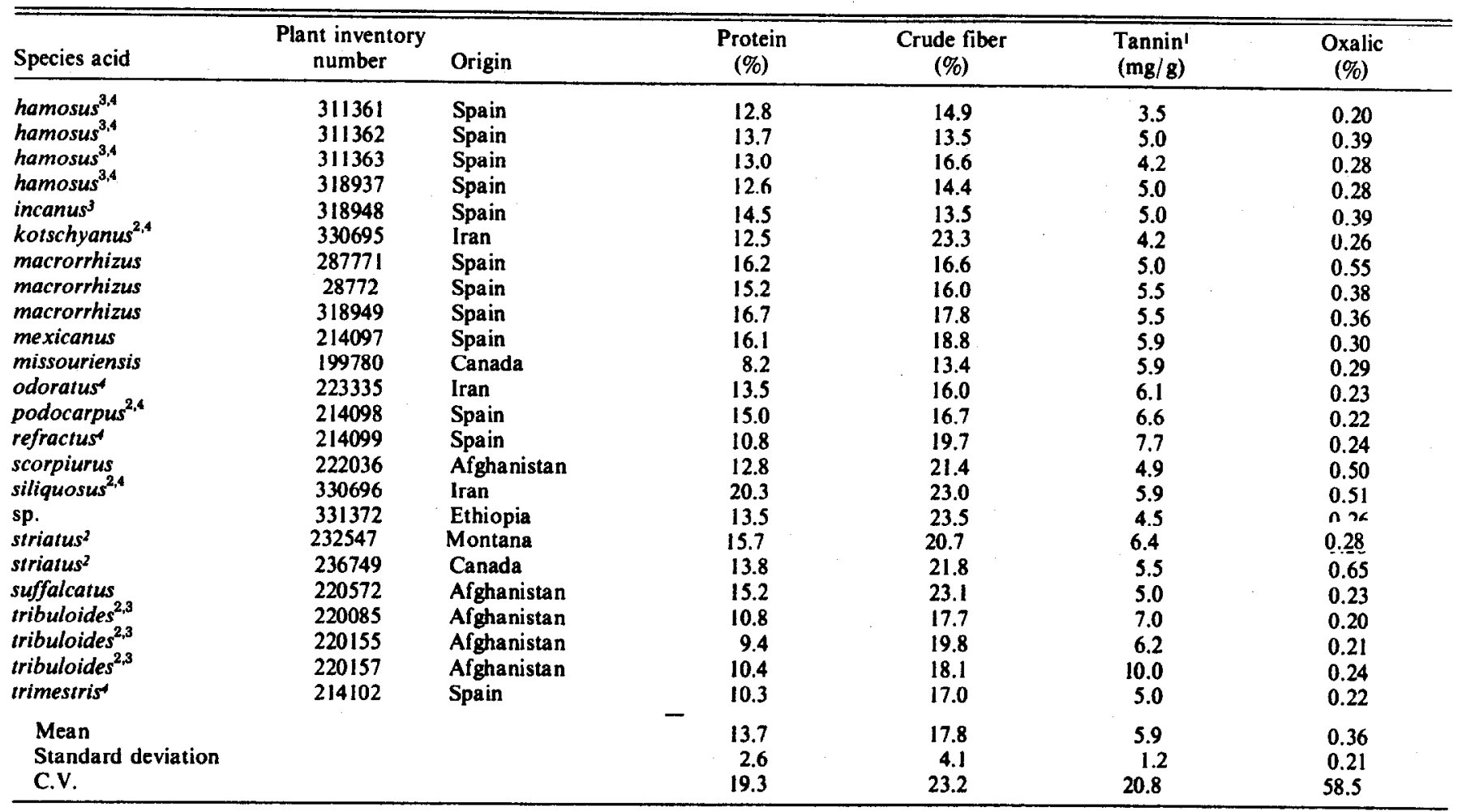

'Gallotanic acid equivalent

2Selenium accumulator

3Annual species.

tContains toxic nitro compounds

\section{Literature Cited}

AOAC. 1970. Official Methods of Analysis. I1 th ed. Association of Official Analytical Chemists. Washington, D.C.

Barmeby, R.C. 1964. Atlas of North American Astragalus. New York Bot. Garden. 1185 p.

Burns, R.E. 1963. Methods of tannin analysis for forage crop evaluation. Georgia Exp. Sta. Tech. Bull. N.S. 32.

Burns, R.E. 1964. Field screening of Lupinus and other plants for alkaloid content. Agron. J. 56:264.

Chamberlain, D.F., and V.A. Mathews. 1969. Materials for the flora of Turkey XVIII Leguminoseae: Astragalus. Notes from the Royal Bot. Garden, Edinburgh. 24:285-310.

Davis, A.M. 1972. Selenium accumulation in Astragalus species. Agron. J. 64:571-574.

Davis, A.M. 1973. Protein, crude fiber, tannin and oxalate concentration of some Astragalus species. Agron. J. 65:613-615.

Donnelly, E.D., and W.B. Anthony. 1969. Relationship of tannin, dry matter digestiblity and crude protein in Sericea lespedeza. Crop Sci. 9:361-362.
Dye, W.B. 1956. Chemical studies of Halogeton glomeratus. Weeds 4:5559.

Komarov, V.L. (ed.), 1965. Flora of the USSR. Vol. XII. Leguminoseae: Astragalus. (Translated from the Russian by the Israel program for scientific translations for the Smithsonian Institute). $681 \mathrm{p}$.

Miller, D.F. 1958. Composition for cereal grains and forages. Nat. Acad. of Sci., Nat. Res. Council. Washington, D.C. Pub. 585. 663 p.

Morton, H.L., R.H. Hans, and L.C. Erickson. 1959. Oxalate and mineral contents of Halogeton glomeratus. Weeds 7:255-264.

Uphof, J.C. Th. 1968. Dictionary of Economic Plants. J. Cramer, Lehre, West Germany. 591 p.

Williams, M.C., and R.C. Barmeby. 1977. The occurrence of nitro-toxins in North American Astragalus (Fabaceae). Brittania 29:310-326.

Williams, M.C., and L.F. James. 1975. Toxicity of nitro-containing Astragalus to sheep and chicks. J. Rnage Manage. 28:260-263.

Williams, M.C., L.F. James, and H.T. Bleak. 1976. Toxicity of introduced nitro-containing Astragalus to sheep, cattle, and chicks. J. Range Manage. $28: 260-263$. 